University of Nebraska - Lincoln

DigitalCommons@University of Nebraska - Lincoln

\title{
Major Herbicides in Ground Water: Results from the National Water-Quality Assessment
}

Jack . E. Barbash

U.S. Geological Survey (USGS)

Gail P. Thelin

U.S. Geological Survey (USGS)

Dana W. Kolpin

U.S. Geological Survey (USGS)

Robert J. Gilliom

U.S. Geological Survey (USGS)

Follow this and additional works at: https://digitalcommons.unl.edu/usgsstaffpub

Part of the Earth Sciences Commons

Barbash, Jack . E.; Thelin, Gail P.; Kolpin, Dana W.; and Gilliom, Robert J., "Major Herbicides in Ground Water: Results from the National Water-Quality Assessment" (2001). USGS Staff-- Published Research. 27.

https://digitalcommons.unl.edu/usgsstaffpub/27

This Article is brought to you for free and open access by the US Geological Survey at DigitalCommons@University of Nebraska - Lincoln. It has been accepted for inclusion in USGS Staff -- Published Research by an authorized administrator of DigitalCommons@University of Nebraska - Lincoln. 


\title{
Major Herbicides in Ground Water: Results from the National Water-Quality Assessment
}

\author{
Jack E. Barbash,* Gail P. Thelin, Dana W. Kolpin, and Robert J. Gilliom
}

\begin{abstract}
To improve understanding of the factors affecting pesticide occurrence in ground water, patterns of detection were examined for selected herbicides, based primarily on results from the National WaterQuality Assessment (NAWQA) program. The NAWQA data were derived from 2227 sites (wells and springs) sampled in 20 major hydrologic basins across the USA from 1993 to 1995 . Results are presented for six high-use herbicides-atrazine (2-chloro-4-ethylamino-6-isopropylamino-s-triazine), cyanazine (2-[4-chloro-6-ethylamino-1,3,5triazin-2-yl]amino]-2-methylpropionitrile), simazine (2-chloro-4,6-bis[ethylamino]-s-triazine), alachlor (2-chloro- $N$-[2,6-diethylphenyl]- $N$ [methoxymethyl]acetamide), acetochlor (2-chloro- $N$-[ethoxymethyl]$N$-[2-ethyl-6-methylphenyl]acetamide), and metolachlor (2-chloro- $N$ [2-ethyl-6-methylphenyl]- $N$-[2-methoxy-1-methylethyl]acetamide)as well as for prometon (2,4-bis[isopropylamino]-6-methoxy-s-triazine), a nonagricultural herbicide detected frequently during the study. Concentrations were $<1 \mu \mathrm{g} \mathrm{L}^{-1}$ at $98 \%$ of the sites with detections, but exceeded drinking-water criteria (for atrazine) at two sites. In urban areas, frequencies of detection (at or above $0.01 \mu \mathrm{g} \mathrm{L}^{-1}$ ) of atrazine, cyanazine, simazine, alachlor, and metolachlor in shallow ground water were positively correlated with their nonagricultural use nationwide $(P<\mathbf{0 . 0 5})$. Among different agricultural areas, frequencies of detection were positively correlated with nearby agricultural use for atrazine, cyanazine, alachlor, and metolachlor, but not simazine. Multivariate analysis demonstrated that for these five herbicides, frequencies of detection beneath agricultural areas were positively correlated with their agricultural use and persistence in aerobic soil. Acetochlor, an agricultural herbicide first registered in 1994 for use in the USA, was detected in shallow ground water by 1995 , consistent with previous field-scale studies indicating that some pesticides may be detected in ground water within 1 yr following application. The NAWQA results agreed closely with those from other multistate studies with similar designs.
\end{abstract}

$\mathrm{T}$ HE widespread use of synthetic organic pesticides over the past several decades has led to their frequent detection in ground water (Barbash and Resek, 1996), surface water (Larson et al., 1997), aquatic biota and sediment (Nowell et al., 1999), and the atmosphere (Majewski and Capel, 1995). Concerns about the potential impacts of pesticides on human health, as well as on terrestrial and aquatic ecosystems, have led to the development of a variety of monitoring and management programs by state and federal agencies. For the protection of ground water, the USEPA is proposing a rule to require that individual states and tribes develop pesticide management plans (PMPs) for the use of pesticides deemed to have a "high leaching potential"-and for which national label or restricted use requirements

J.E. Barbash, U.S. Geological Survey (USGS), 1201 Pacific Ave., Suite 600, Tacoma, WA 98402; G.P. Thelin and R.J. Gilliom, USGS, Placer Hall, 6000 J Street, Sacramento, CA 95819-6129; and D.W. Kolpin, USGS, 400 S. Clinton St., Box 1230, Iowa City, IA 52244. Received 4 Jan. 2000. *Corresponding author (jbarbash@usgs.gov).

Published in J. Environ. Qual. 30:831-845 (2001). are unlikely to "ensure adequate protection of ground water"-but whose use is not cancelled on a national basis (USEPA, 1991, 1993a). The first set of proposed PMPs will focus on four herbicides that are used primarily for agricultural purposes; atrazine, simazine, alachlor, and metolachlor, hereafter referred to as the PMP herbicides. Cyanazine was originally included in the PMP list, but subsequently removed with the cancellation of its registration for all uses in December 1999 (Jones, 2000). As the PMPs evolve, their analytical scope may expand to include other pesticides and pesticide transformation products (Browner, 1996).

This paper summarizes data on the occurrence of the four PMP herbicides and three additional herbicides in ground water of the USA, and uses this information to examine how the use, persistence, and mobility of these compounds, as well as other factors such as well depth and study design influence the likelihood of detecting pesticides in ground water. Most of the data were derived from sampling conducted between 1993 and 1995 as part of the National Water-Quality Assessment (NAWQA) program of the U.S. Geological Survey (USGS).

The principal objectives of the NAWQA program are "to describe the status of and trends in the quality of the Nation's ground water and surface water resources and to link assessment of status and trends with an understanding of the natural and human factors that affect the quality of water" (Gilliom et al., 1995, p. 2). The NAWQA program measures the concentrations of a large number of pesticides and pesticide transformation products, as well as a wide variety of other chemical constituents in ground water, surface water, stream sediments, and aquatic biota in 59 major hydrologic basins, or study units across the USA, representing approximately 60 to $70 \%$ of the water use in the Nation.

The NAWQA program has involved the most geographically extensive study of pesticides and pesticide transformation products in ground water of the USA to be conducted in the past decade. Among the other multistate studies carried out to date, only the National Pesticide Survey (NPS), conducted by the USEPA from 1988 to 1990 (USEPA, 1992a), was of comparable geo-

\footnotetext{
Abbreviations: a.i., active ingredient; CGAS, Ciba-Geigy Atrazine Study; DRASTIC, Depth to water, net Recharge, Aquifer media, Soil media, Topography, Impact of the unsaturated zone, and hydraulic Conductivity of the aquifer; HAL, lifetime health advisory level; LUS, land-use study (NAWQA study component); MCL, maximum contaminant level; MDL, method detection limit; MMS, Metolachlor Monitoring Study; MWPS, Midwest Pesticide Study; NAWQA, National Water-Quality Assessment; NAWWS, National Alachlor WellWater Survey; NPS, National Pesticide Survey; PMP, pesticide management plan; SUS, subunit survey (NAWQA study component); $t_{1 / 2}$ half-life for transformation in aerobic soil; USDA-ARS, U.S. Department of Agriculture-Agricultural Research Service; USEPA, U.S Environmental Protection Agency; USGS, U.S. Geological Survey.
} 
graphic scope. The NAWQA program builds upon the results from the NPS in several ways, including: (i) the use of more sensitive analytical methods for pesticides and their transformation products; (ii) the incorporation of chemical analyses for more recently introduced pesticides, additional pesticide transformation products and a broad range of other chemical constituents; and (iii) a focus on ground water quality, rather than well water quality. Barbash et al. (1999) provide a detailed comparison of the design of the NAWQA program with those of other multistate studies of pesticides in ground water.

In addition to the four PMP herbicides, the seven compounds examined in this paper include cyanazine, prometon, and acetochlor. Although as noted earlier, cyanazine was removed from the original PMP list following the cancellation of its registration, discussion of the data for this compound was retained to further illustrate how the use patterns and persistence of highuse pesticides influence the likelihood of their detection in ground water. Prometon is examined because it is used almost exclusively for nonagricultural purposes (Capel et al., 1999) and was the herbicide detected most frequently in ground water beneath urban areas during the NAWQA program (Kolpin et al., 1998a). Inclusion of this herbicide thus expands the scope of this analysis beyond predominantly agricultural pesticides. Acetochlor is an agricultural herbicide first introduced in the USA in 1994 (Kolpin et al., 1996a) to partially replace the use of atrazine and alachlor. Data on its occurrence in ground water provide an indication of the time required for a pesticide to reach detectable concentrations in ground water - if it does so at all-following initiation of its widespread use. Cyanazine, prometon, and acetochlor were also included because of their chemical similarity to the PMP herbicides; cyanazine and prometon, like atrazine and simazine, are triazine compounds, while acetochlor, like alachlor and metolachlor, is an acetanilide.

An earlier summary by Kolpin et al. (1998a) provided a preliminary overview of the occurrence data for 46 of the 83 pesticides and pesticide transformation products examined in ground water by the NAWQA program from 1993 to 1995. The present discussion-and the more extensive report upon which it is based (Barbash et al., 1999)—builds upon the Kolpin et al. (1998a) summary by focusing more closely on seven of these compounds from several different perspectives. For these seven compounds, or various subsets thereof, this paper: (i) compares the ranges of observed concentrations with existing drinking-water criteria; (ii) examines the extent to which frequencies of detection in shallow ground water during the NAWQA program were correlated with the use, mobility, and persistence of the herbicides, as well as with well depth; (iii) summarizes data from this and other USGS studies to examine the timing of acetochlor detections in ground water, relative to when the herbicide was first applied in the USA; (iv) uses comparisons with the results from other multistate studies to infer how study design can influence the frequencies of pesticide detection in ground water; and (v) compares the spatial distributions of herbicide detections in ground water beneath different land-use settings across the nation (agricultural, urban, and mixed) with the geographic patterns of agricultural use of these compounds.

\section{METHODS}

\section{Design of the National Water-QualityAssessment}

The ground water quality data summarized here are from the subunit survey and land-use study components of the NAWQA program (Gilliom et al., 1995; Squillace et al., 1996). Subunit surveys [SUSs, originally termed study unit surveys by Gilliom et al. (1995) and Squillace et al. (1996)] provide large-scale spatial assessments of the quality of water drawn from aquifers representing current or future sources of drinking water (referred to as drinking water aquifers in this paper). This is accomplished by sampling existing wells of widely varying depths and selected springs-and thus, ground water of widely varying ages - across large sections of individual study units, referred to as aquifer subunits. Because their boundaries are established by hydrogeologic rather than anthropogenic features, most of the SUSs sample areas of mixed land use, i.e., areas where no single type of land use predominates.

Land-use studies (LUSs) involve the sampling of either existing or newly installed wells to assess the quality of shallow ground water in more limited areas dominated by specific types of land use. The LUSs target ground water recharged within approximately $10 \mathrm{yr}$ before sampling; local understanding of the hydrologic system (e.g., Cowdery, 1997), as well as concentrations of chlorofluorocarbons, ${ }^{3} \mathrm{H}$ (tritium), ${ }^{3} \mathrm{He}$, and $\mathrm{SF}_{6}$ measured at selected sites (C.V. Price, USGS, personal communication, 2000) generally indicated that this objective was met for most of the wells sampled during these studies. To maintain a consistent level of effort from one year to the next, the NAWQA program concentrates the majority of its sampling into a 3-yr high-intensity phase in approximately one-third of the study units at any point in time. Long-term variations in water quality are observed through the use of a rotating cycle in each study unit-3 yr of intensive sampling followed by $6 \mathrm{yr}$ of relatively low-intensity activity (Gilliom et al., 1995).

This paper summarizes selected SUS and LUS results for wells and springs sampled from 1993 to 1995, during the first round of 20 NAWQA study-unit investigations. The broad geographic distribution of the areas sampled (Barbash et al., 1999) ensured that these SUSs and LUSs covered a wide range of physiographic and climatic regions. Although the 1993-1995 LUSs focused on a variety of different land-use settings, only those conducted in agricultural and urban (including suburban) areas were sufficiently numerous to merit discussion here. Furthermore, the only LUSs or SUSs examined are those for which 10 or more sites were sampled for pesticide analyses. As a result of applying these selection criteria, data from 2227 of the approximately 2558 wells and springs sampled for pesticides from 1993 to 1995 were included in the present analysis. The agricultural LUSs were focused on areas dominated by the cultivation of specific field crops, pasture, or orchards (Kolpin et al., 1998a), and selected using an agricultural classification system developed for the NAWQA program by Gilliom and Thelin (1997). The urban LUSs were conducted in major metropolitan areas, typically the largest within each study unit of interest. Maps showing the locations of the NAWQA study units and the specific areas sampled during the LUSs and SUSs have been provided by Barbash et al. (1999), along with a tabular summary of the principal 
design features of these studies, including their geographic settings, hydrogeologic characteristics, types and numbers of wells sampled, and median well depths. This table is also available on the World Wide Web at http://water.wr.usgs.gov/ pnsp/fy91sum.html.

\section{Sampling and Chemical Analyses}

The wells sampled for this investigation were either preexisting or newly installed for the NAWQA Program using the selection methods or installation procedures described by Lapham et al. (1995). All ground water samples were obtained using the methods summarized by Koterba et al. (1995). Many of the NAWQA sites were sampled more than once for pesticides during these studies, but the data discussed here include only one sample per site-typically the first one taken. Exceptions to the latter approach occurred in two different situations. First, for those networks where the initial sampling involved only a subset of all the sites within the network, the data used were those from the year when all of the wells in the network were sampled for pesticides. Second, at sites where the first sampling involved analyses for only a subset of all the targeted pesticides and pesticide transformation products (see below), the data used were those from the sampling when analyses for the full suite of pesticides and transformation products of interest were carried out.

During the 1993-1995 sampling period for the NAWQA Program, chemical analyses were carried out for 76 pesticides and 7 pesticide transformation products (Gilliom et al., 1999). The method employed for the analysis of all seven herbicides of interest to this discussion involved solid-phase extraction onto $\mathrm{C}_{18}$ cartridges followed by capillary-column gas chromatography-mass spectrometry (Zaugg et al., 1995). The method detection limits (MDLs) for the seven herbicides, listed in Table 1, were considerably lower than those for most other large-scale studies of pesticide occurrence in ground water (Barbash and Resek, 1996). However, the MDLs were determined using standard procedures established by the USEPA (1992b) to represent "the minimum concentration of a substance that can be identified, measured, and reported with $99 \%$ confidence that the compound concentration is greater than zero" (Zaugg et al., 1995, p. 22).

As noted by Kolpin et al. (1998a), the MDLs for the NAWQA program provide an indication of the relative sensitivities of the analytical methods to the different compounds examined, but they were not used as thresholds for reporting detections. Instead, pesticide detections were reported when specific analytical identification criteria were met, based on gas chromatographic retention times and mass spectral peak areas, rather than concentration thresholds (Zaugg et al., 1995). For this reason, concentrations reported for individual pesticides in this and other publications from the NAWQA program are, in some instances, lower than the MDL for the compound of interest (e.g., Domagalski et al., 1997; Kolpin et al., 1998a; Capel et al., 1999; Martin et al., 1999).

In addition to the MDL data, Table 1 also summarizes the frequencies of detection in ground water field blanks for the seven herbicides during the period of sampling, and compares these results with the frequencies of detection in all of the ground water samples examined for this study. Each field blank consisted of pesticide-free water that was passed through the field sampling equipment after (i) a ground water sample was taken and (ii) the sampling equipment was decontaminated using standard NAWQA procedures (Koterba et al., 1995). According to Martin et al. (1999), cross-contamination (as observed and quantified in field blanks) need not be considered in the interpretation of detections of an individual pesticide or pesticide transformation product in environmental samples if the ratio of the frequency of detection at any concentration in the environmental samples to the frequency of detection at any concentration in field blanks is greater than 5.0. Based on this criterion, the detections in the field blanks (Table 1) were at sufficiently low frequencies to conclude that cross-contamination did not interfere significantly with the interpretation of the ground water data for any of the seven herbicides of interest.

The data examined in this paper included detections below the MDL for three of the seven herbicides of interestprometon, simazine, and metolachlor. Furthermore, the results shown in Table 1 suggest that some of the detections below the MDL (particularly some of those for prometon and simazine) may have been caused by cross-contamination. However, because the methods introduced by Martin et al. (1999) are based on the criteria described by Zaugg et al. (1995) — rather than MDLs - for analyte detections, they account for the potential influence of cross-contamination below, as well as above, the MDL.

All other factors being equal, studies that employ lower reporting limits for a given pesticide have generally observed higher frequencies of its detection in ground water than studies using higher reporting limits (e.g., Burkart and Kolpin, 1993; Barbash and Resek, 1996). This inverse relation makes it difficult to compare detection frequencies among different compounds, different studies, or different phases of the same study if reporting limits are not uniform. To compensate for this,

Table 1. Method detection limits (MDLs), frequencies of detection at all concentrations and below the MDL in ground water samples (1993-1995), and frequencies of detection at all concentrations and below the MDL in ground water field blanks (1992-1995) during the NAWQA program for the seven herbicides of interest.

\begin{tabular}{|c|c|c|c|c|c|c|c|}
\hline \multirow[b]{2}{*}{ Herbicide } & \multirow[b]{2}{*}{ MDL $\dagger$} & \multirow{2}{*}{$\begin{array}{c}\text { No. of } \\
\text { sites } \\
\text { sampled } \leftarrow\end{array}$} & \multicolumn{2}{|c|}{$\begin{array}{l}\text { Frequency of detection } \\
\text { in ground water samplesț }\end{array}$} & \multirow{2}{*}{$\begin{array}{l}\text { No. of } \\
\text { field } \\
\text { blanks\$ }\end{array}$} & \multicolumn{2}{|c|}{$\begin{array}{l}\text { Frequency of detection } \\
\text { in ground water field blanks }\end{array}$} \\
\hline & & & $\begin{array}{c}\text { All } \\
\text { concentrations }\end{array}$ & $\begin{array}{l}\text { Detections } \\
\text { below MDL }\end{array}$ & & $\begin{array}{c}\text { All } \\
\text { concentrations }\end{array}$ & $\begin{array}{l}\text { Detections } \\
\text { below MDI }\end{array}$ \\
\hline & $\mu g \mathbf{L}^{-1}$ & & 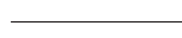 & 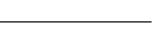 & & 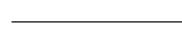 & 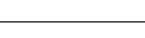 \\
\hline Atrazine & 0.001 & 2227 & 30.1 & $\mathbf{0}$ & 145 & 2.8 & $\mathbf{0}$ \\
\hline Cyanazine & 0.004 & 2227 & 1.0 & 0 & 145 & 0 & 0 \\
\hline Prometon & 0.018 & 2227 & 11.8 & 5.7 & 145 & 0.7 & 0.7 \\
\hline Simazine & 0.005 & 2227 & 14.3 & 2.8 & 145 & 1.4 & 1.4 \\
\hline Acetochlor & 0.002 I & 953 & 0.2 & $\mathbf{0}$ & 15 & $\mathbf{0}$ & $\mathbf{0}$ \\
\hline Alachlor & 0.002 & 2227 & 2.2 & 0 & 145 & 0 & $\mathbf{0}$ \\
\hline Metolachlor & 0.002 & 2227 & 11.7 & 0.6 & 145 & 1.4 & 0 \\
\hline
\end{tabular}

$\dagger$ Data from Zaugg et al. (1995) for all compounds except acetochlor.

+ Data include all LUS and SUS sites discussed in this report.

$\S$ Data from Martin et al. (1999).

II MDL value from Lindley et al. (1996). 
detection frequencies were computed on the basis of a common reporting limit for any such comparisons examined in this paper. The reporting limit used here to compare results among different compounds or different study components for the NAWQA program was $0.01 \mu \mathrm{g} \mathrm{L}^{-1}$. (Although the MDL for prometon is $0.018 \mu \mathrm{g} \mathrm{L}^{-1}$, the use of the data on detections below the MDLs made it possible to use the 0.01 $\mu \mathrm{g} \mathrm{L}^{-1}$ reporting limit for the herbicide in these comparisons.) Because the MDLs for the NAWQA program were lower than or equal to those used by other multistate studies of pesticide occurrence in ground water, when the NAWQA results for an individual pesticide were compared with those from another study, the reporting limit for the other study was employed for the comparison (Barbash et al., 1999).

\section{Estimating Chemical Use}

To investigate statistical and geographic relations between herbicide detections and use, quantitative estimates of the intensity of chemical applications (i.e., the mass of active ingredient applied per unit area) were assembled for three different spatial scales; nationwide, countywide, and individual LUSs. However, the finest spatial scale at which such information could be obtained in a consistent format nationwide was on a countywide basis, and only for pesticide applications in agricultural settings (Gianessi and Anderson, 1996). Estimates of nonagricultural pesticide use were considerably more limited, and available only at a national scale (Gianessi and Puffer, 1990). As a result, geographic variations in herbicide use were only examined for agricultural settings. Furthermore, among the seven parent compounds of interest, quantitative nationwide data on use in both agricultural and nonagricultural settings were available only for the four PMP herbicides and cyanazine.

Agricultural herbicide use was computed for two spatial domains. Using the methods described below, estimates of use within a circle, or buffer of $1 \mathrm{~km}$ radius surrounding each of the sites sampled for the agricultural LUSs were calculated to examine statistical correlations between herbicide use and detection frequencies during these studies. [Data from one of the SUSs were included in the analysis because this SUS, conducted in central Nebraska, involved the sampling of shallow ground water in an area dominated by row-crop agriculture (Barbash et al., 1999.)] The intensity of herbicide use was also calculated on a countywide basis for the construction of maps displaying geographic patterns of herbicide detection and use across the nation.

\section{Use Estimates for Agricultural Land-Use Studies}

For each agricultural LUS, an estimate of agricultural use was obtained for each herbicide through the following procedure.

1. Using a geographic information system, the $1-\mathrm{km}$ buffers surrounding the individual sampling sites were superimposed on USGS land-use and land-cover data (USGS, 1990) to compute the area of each buffer mapped as agriculture, including orchards, vineyards, and pasture, based on the Anderson Level II classification system (Anderson et al., 1976).

2. For each of the crops to which the herbicide may have been applied, county-based data from the 1992 Census of Agriculture (U.S. Dep. of Commerce, 1995) were used to estimate the area of the crop harvested within each $1-\mathrm{km}$ buffer.

3. The area of each crop within each buffer was multiplied by a statewide estimate of the percentage of that crop to which the herbicide was applied (Giannesi and Anderson, 1996).
4. The estimated crop area to which the herbicide was applied within each buffer was multiplied by a statewide estimate of the average rate of application of the active ingredient to that crop (Gianessi and Anderson, 1996).

5. The total amount of active ingredient applied within each buffer was computed as the sum of the amounts applied to individual crops in the buffer.

6. The total amount of active ingredient applied within the LUS network was calculated as the sum of the amounts applied in the buffers surrounding all of the sites sampled in the network.

7. The total amount of active ingredient applied within all of the buffers in the LUS network was divided by the total area of all the buffers to estimate the mass applied per unit area.

Although this approach may have underestimated the intensity of use for some compounds in areas dominated by low-use crops (especially atrazine use on pasture), it was intended to account for use on every crop for which use data were available for each herbicide. This approach has been described in greater detail by Thelin and Gianessi (2000), who employed these methods to estimate pesticide use within individual drainage basins, rather than $1-\mathrm{km}$ buffers.

\section{Use Estimates for Individual Counties}

Estimates of the total agricultural use of individual herbicides per unit area of harvested cropland were also computed for each county of the USA, based on the work of Thelin and Gianessi (2000). These estimates were obtained by adding together the total amount of active ingredient applied to agricultural crops and pasture in the county (Gianessi and Anderson, 1996) and dividing by the total area of harvested cropland and pasture in the county, based on the 1992 Census of Agriculture (U.S. Dep. of Commerce, 1995).

\section{Selection of Data on Herbicide Properties}

The soil organic $\mathrm{C}$ partition coefficient, or $K_{\mathrm{oc}}$, is a measure of the tendency of a compound to partition into soil organic $\mathrm{C}$ from aqueous solution, and was therefore used to provide a quantitative, inverse indication of herbicide mobility in ground water. For this paper, half-lives for transformation in aerobic soil were used to quantify persistence, rather than the more commonly cited field dissipation half-lives, because aerobic soil half-lives are not affected by offsite transport, and are measured under conditions that are more controlled than those employed for field dissipation studies (USDA-ARS, 1995; Barbash and Resek, 1996).

Table 2 summarizes data on $K_{\text {oc }}$ and aerobic soil half-life for the seven herbicides. Although several comprehensive summaries of these properties have been published for pesticides (e.g., Kenaga, 1980; Nash, 1988), the parameter values in the table were taken from two of the most widely cited and readily available compilations of such data, the USDA-ARS Pesticide Properties Database (USDA-ARS, 1995), and the USEPA Pesticide Environmental Fate "One-Line Summaries" (USEPA, 1993b, 1994a,b,c, 1995, 1996a,b), the latter so named for their brevity. The data in Table 2 demonstrate the considerable variability in parameter values that have been reported for many of these compounds, sometimes spanning an order of magnitude or more.

For each herbicide, Table 2 lists the $K_{\mathrm{oc}}$ and aerobic soil half-life values selected for the statistical analyses. In most instances, this value was the one recommended by the authors of the USDA-ARS (1995) database. For the aerobic soil halflife, when multiple values were available for a given herbicide but none was recommended, the value measured in a loam 
soil (silty loam, loamy silt, or silty clay loam) was the one selected. Both transformation rate (e.g., Nash, 1988) and, for many compounds, $K_{\text {oc }}$ (e.g., Bailey and White, 1964; Schwarzenbach et al., 1993), are known to vary considerably with temperature, but the temperature of measurement was seldom provided for either parameter by the sources consulted (USDA-ARS, 1995; USEPA, 1993b, 1994a,b,c, 1995, 1996a,b)a situation commonly encountered in the literature (Barbash and Resek, 1996).

\section{Statistical Analyses}

Simple linear correlations, Spearman rank correlations, and multiple linear regression were employed to examine statistical relations between the frequencies of herbicide detection in shallow ground water during the LUSs and a variety of explanatory variables. (All statistical tests were evaluated at a significance level $[\alpha]$ of 0.05 .) Unlike simple linear correlations and multiple linear regressions, which are both parametric techniques, Spearman rank correlations are nonparametric. A nonparametric analogue to a standard correlation coefficient for the relation between two variables, Spearman's $\rho$ is computed by replacing the individual values for each variable with their respective ranks among the other values for that variable, and then computing a correlation coefficient $(\rho)$ using the ranks, rather than the original data (Helsel and Hirsch, 1992).

These analyses focused on the LUS results, rather than those from the SUSs, for two reasons. First, the effects of pesticide use (the variable of principal interest in this analysis) on ground water quality are more likely to be evident in shallow ground water than in deeper aquifers. Second, relations between occurrence and use are more easily discerned in areas of relatively homogeneous land use than in those with mixed land use.

As is often the case for anthropogenic contaminants in environmental media, the frequencies of herbicide detection among the different LUS areas were strongly skewed toward low values. The intensities of agricultural use among the LUS areas were similarly distributed. To obtain distributions that more closely approximated normality, both parameters were therefore subjected to a log transformation before examining all parametric statistical relations between occurrence and use in agricultural areas for the NAWQA study. To accomodate this transformation, in all cases where an herbicide was not detected at or above $0.01 \mu \mathrm{g} \mathrm{L}^{-1}$ in a particular agricultural LUS, its detection frequency was assigned a value of $1 \%$ (smaller than the lowest nonzero detection frequency for any of the herbicides in any of the LUSs) before the transformation was applied. Similarly, for every agricultural LUS in which the total agricultural use of a given herbicide within the 1-km buffers surrounding all sampled sites was zero, the agricultural use was assigned a value of $0.001 \mathrm{~kg}$ of active ingredient per square kilometer (smaller than the smallest use value for any herbicide in any LUS network) to accomodate the log transformation. Five sites for which agricultural use data were not available, out of a total of 995 sites, were excluded from this analysis (Barbash et al., 1999).

\section{RESULTS AND DISCUSSION \\ Concentrations in Relation to Drinking-Water Quality Criteria}

The concentrations at which the seven herbicides were detected in ground water from 1993 to 1995 during
Table 2. Soil organic $\mathrm{C}$ partition coefficients $\left(K_{\mathrm{oc}}\right)$ and half-lives for transformation in aerobic soils for the seven herbicides of interest.

\begin{tabular}{|c|c|c|c|c|}
\hline \multirow[b]{2}{*}{ Herbicide } & \multicolumn{2}{|r|}{$K_{\mathrm{oc}}$} & \multicolumn{2}{|c|}{$\begin{array}{c}\text { Half-life for transformation } \\
\text { in aerobic soil }\end{array}$} \\
\hline & $\begin{array}{c}\text { Selected } \\
\text { value } \dagger\end{array}$ & $\begin{array}{c}\text { Range of values } \\
\text { in sources } \\
\text { consulted } \ddagger\end{array}$ & $\begin{array}{c}\text { Selected } \\
\text { value } \dagger\end{array}$ & $\begin{array}{c}\text { Range of values } \\
\text { in sources } \\
\text { consulted } \ddagger\end{array}$ \\
\hline & & $\mathrm{mL} / \mathrm{g}$ & & days \\
\hline Atrazine & 147 & 38-288 & 146 & 21-330 \\
\hline Cyanazine & 218 & $40-235$ & 17 & 10-98 \\
\hline Prometon & 95 & 32-300 & 932 & $>365,932$ \\
\hline Simazine & 140 & 103-230 & 91 & 36-234 \\
\hline Acetochlor & $239 \S$ & 74-428 & $14 \S$ & 8-110 \\
\hline Alachlor & 124 & 43-209 & $\sim 21$ & 14-21 \\
\hline Metolachlor & 70 & 22-307 & 26 & 26,67 \\
\hline
\end{tabular}

† Values obtained from USDA-ARS (1995) for all compounds except acetochlor. See text for methods used to select data from among multiple values in data sources. No temperature(s) of measurement provided in USDA-ARS (1995) for either $K_{\text {oc }}$ or half-life in aerobic soil.

+ Data obtained from USDA-ARS (1995) and USEPA (1993b; 1994a,b,c; 1995; 1996a,b). Temperature(s) of measurement seldom provided for either $K_{0 c}$ or half-life in aerobic soil.

§ Data obtained from USEPA (1994a).

the NAWQA study are shown in Fig. 1. For each herbicide, these results are presented for four sampling components; shallow ground water sampled in agricultural areas (agricultural LUSs), urban areas (urban LUSs), and areas of mixed land use (SUSs sampling shallow ground water), and deeper ground water sampled in areas of mixed land use (deeper SUSs). An SUS was considered to have sampled shallow ground water "if the wells sampled showed evidence of being influenced by recent recharge and were of generally comparable depth to LUS wells in the same area" (Gilliom et al., 1998, p. 8).

Consistent with observations reported by previous large-scale studies of pesticide concentrations in ground water (Barbash, 1995), 98\% of the detections of the seven herbicides were at concentrations $<1 \mu \mathrm{g} \mathrm{\textrm {L } ^ { - 1 }}$. Consequently, water-quality criteria for the protection of drinking water (USEPA, 2000) were rarely exceeded (Fig. 1). Among the seven herbicides, exceedances of maximum contaminant levels (MCLs) or lifetime health advisory levels (HALs) during the NAWQA study occurred at two of the 2227 sites of interest, and only for atrazine. Both sites were shallow (LUS) wells; one was located in an agricultural area and the other was used for drinking water in an urban area. However, simple assessments of risk based solely on comparisons of contaminant concentrations with drinking-water quality criteria should be viewed with caution because, for a variety of reasons described elsewhere (e.g., Kolpin et al., 1998a; Barbash et al., 1999; Gilliom et al., 1999), use of these criteria may underestimate the health risks to humans or aquatic organisms.

\section{Frequencies of Detection}

Of the seven herbicides of interest, all but acetochlor were among the 10 pesticides or pesticide transformation products detected most often in ground water during the 1993-1995 NAWQA sampling (Kolpin et al., 1998a; Barbash et al., 1999; USGS, 1999). Frequencies 
of detection at or above $0.01 \mu \mathrm{g} \mathrm{L}^{-1}$ in ground water are shown in Fig. 2. These results are displayed for the same four study components examined in Fig. 1.
Variations in the frequencies of detection among the different herbicides and study components provide clues regarding the effects of a variety of natural and anthro-

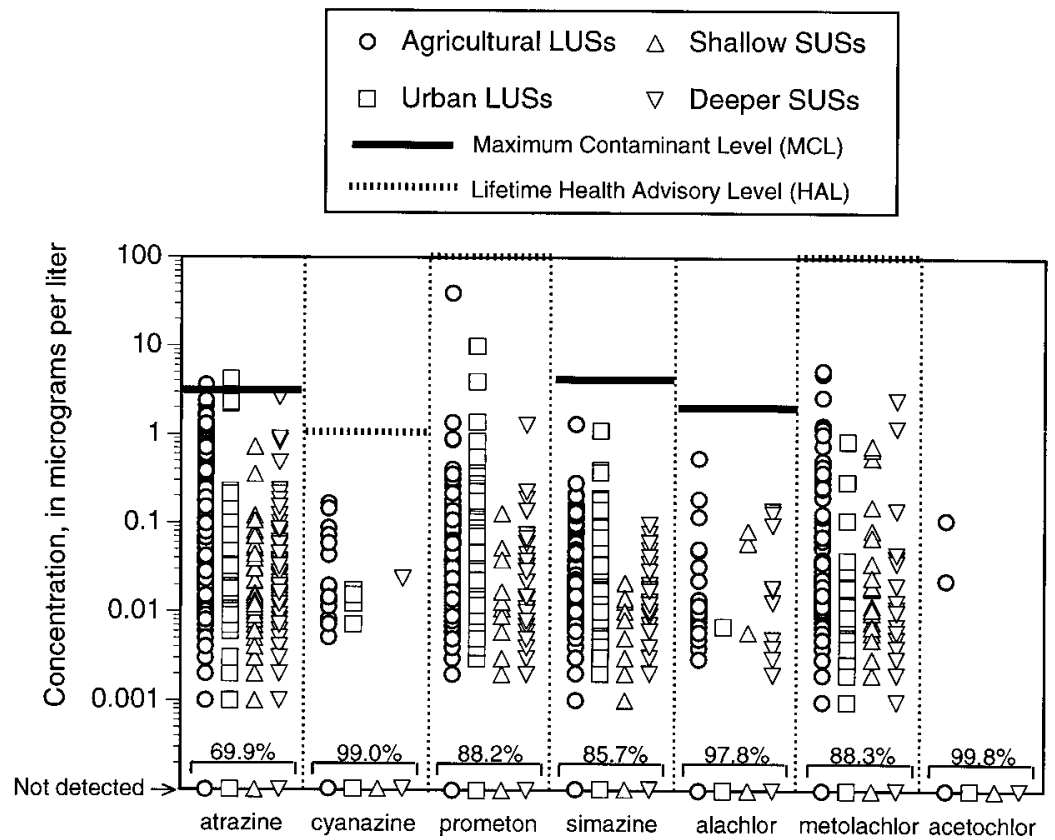

Fig. 1. Concentrations of herbicides measured in ground water at individual sites during the NAWQA investigation, in relation to drinkingwater quality criteria (USEPA, 2000). Lifetime health advisory level (HAL) shown for herbicides for which no maximum contaminant level (MCL) has been established. (Neither criterion has yet been established for acetochlor.) Overall percentage of sites with no detections given above the not detected symbols for each herbicide. Number of sites sampled for each study component given in Fig. 2. LUSs, land-use studies; SUSs, subunit surveys.

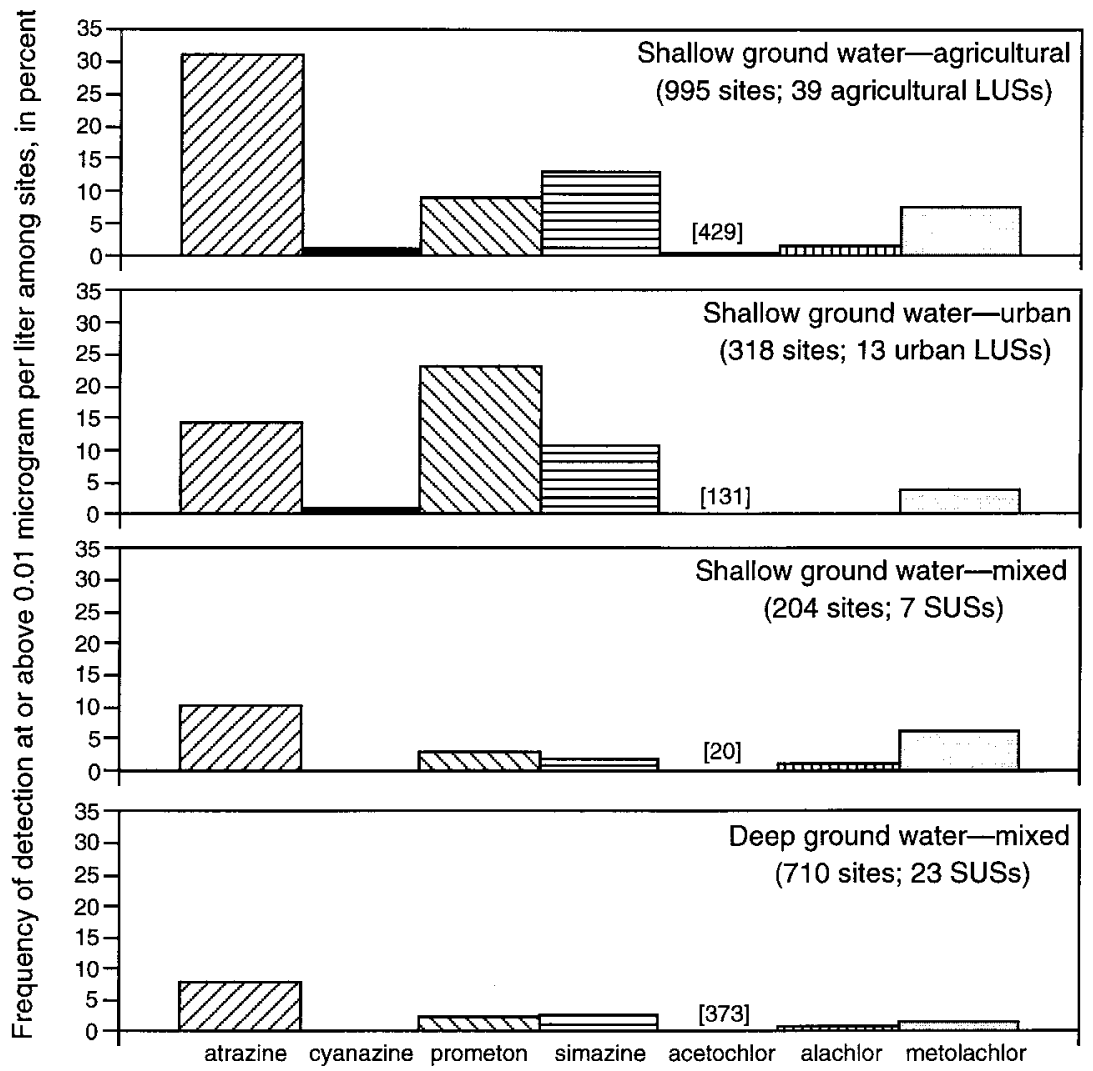

Fig. 2. Frequencies of herbicide detection in ground water from 1993 to 1995 , by study component, during the NAWQA investigation. Numbers of sites sampled for acetochlor given in brackets. LUSs, land-use studies; SUSs, subunit surveys. 
pogenic factors on the likelihood of detecting these compounds in ground water. The influences of several of these factors are examined below.

\section{Relations between Chemical Use and Herbicide Detections}

It is reasonable to suppose that the areas where a pesticide is used more intensively are those where it is more likely to be detected in ground water. However, the evidence in support of this hypothesis is remarkably sparse (e.g., Barbash and Resek, 1996; Kolpin et al., 1998a), perhaps in part because of the limitations in the spatial and temporal resolution of the available data on pesticide use, mentioned earlier. Figure 3 provides estimates of the total amounts of each of the seven herbicides used annually for agricultural and nonagricultural purposes across the USA, and lists the settings in which they have been applied most commonly. Historical trends in the agricultural use of these herbicides from 1964 to 1994 were presented by Barbash et al. (1999).

\section{General Relations between Occurrence and Land-Use Setting}

Atrazine was the herbicide detected in ground water most frequently during all of the NAWQA study components of interest except for the urban LUSs (Fig. 2). Atrazine was also the pesticide detected most frequently in ground water by many other multistate (Kolpin et al., 1996b; Holden et al., 1992) and statewide studies (Goetsch et al., 1992; Kross et al., 1990; Steichen et al., 1988; Klaseus et al., 1988; Sievers and Fulhage, 1992; Exner and Spalding, 1990) in the USA, as well as Provincewide investigations in Ontario, Canada (Rudolph et al., 1992, 1993). These observations are not unexpected, given that atrazine has been the pesticide used most extensively in the USA during the past two decades (Majewski and Capel, 1995), as well as one of the most widely used pesticides in Ontario (Rudolph et al., 1992).

Nationwide use data are not currently available for prometon, but the higher frequency of its detection relative to atrazine in shallow ground water beneath urban areas (Fig. 2) parallels the relative frequencies of use

\section{Agricultural Use}
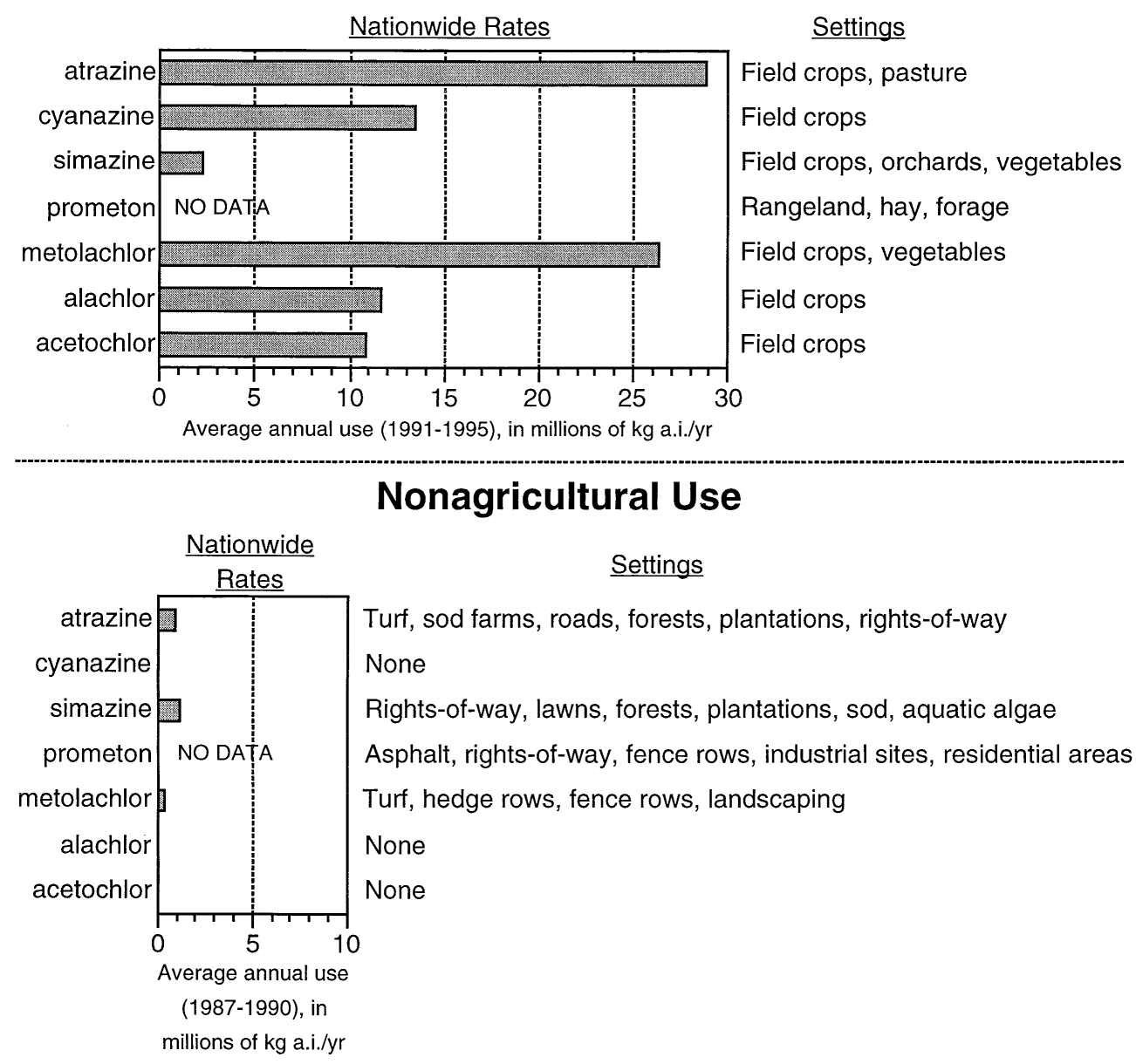

Fig. 3. Agricultural and nonagricultural use of the seven herbicides of interest. Estimates of nationwide rates of agricultural use per year are from 1991 to 1995 (Gianessi and Anderson, 1996); estimates for rates of nonagricultural use per year are from 1987 to 1990 (Gianessi and Puffer, 1990). Information on application settings was obtained from Gianessi and Puffer (1990) for agricultural use, and from a variety of sources for nonagricultural use. a.i., active ingredient. 

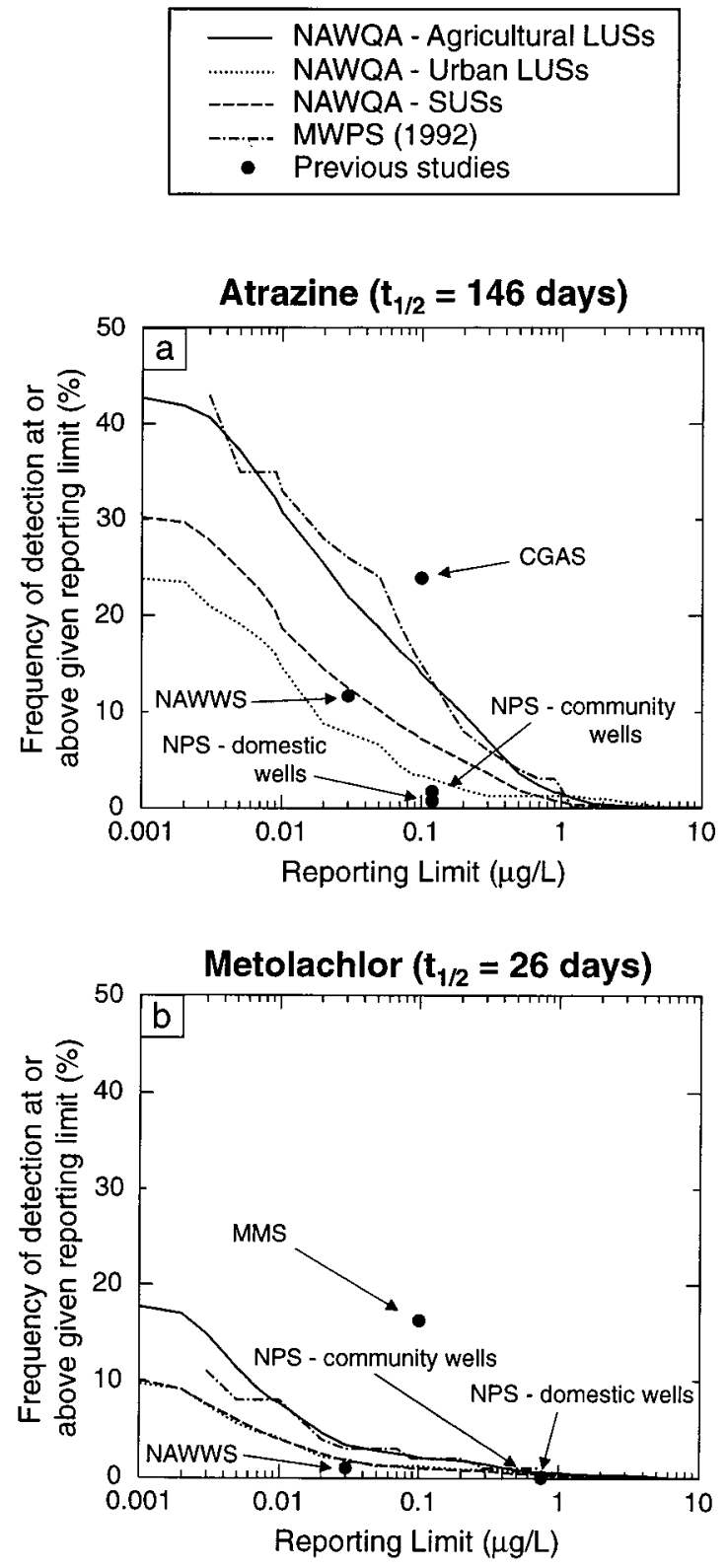

Fig. 4. Frequencies of herbicide detection in ground water for the multistate studies in relation to reporting limits for $(a)$ atrazine, and $(b)$ metolachlor. CGAS, Ciba-Geigy Atrazine Study (Balu et al., 1998); LUSs, land-use studies; MMS, Metolachlor Monitoring Study (Roux et al., 1991); MWPS, Midwest Pesticide Study (Kolpin et al., 1995); NAWWS, National Alachlor Well-Water Survey (Holden et al., 1992); NPS, National Pesticide Survey (USEPA, 1990, 1992a); SUSs, subunit surveys; $t_{1 / 2}$, half-life for transformation in aerobic soil.

of the two herbicides in residential settings. According to Whitmore et al. (1992), in 1990, prometon was applied outdoors in residential areas 1281000 times, while atrazine was applied 477000 times. Other studies also have observed close associations between urban land use and prometon occurrence in ground water (e.g., Burkart and Kolpin, 1993), including several conducted as part of the NAWQA program (Christenson and Rea, 1993; Ator and Ferrari, 1997; Kolpin et al., 1998a). The relatively frequent detection of prometon during the agricultural LUSs, however (Fig. 2), indicates that its use may also be extensive in agricultural areas, albeit for noncrop applications.

The detection in urban areas of cyanazine (Fig. 1 and 2 ), an herbicide used only in agricultural settings (Fig. 3 ), may have been the result of historical applications, atmospheric deposition, or transport from nearby application areas, either in the air (for example, via spray drift) or in ground water. Similarly, atrazine and metolachlor may also have reached the shallow ground water in the urban areas by atmospheric or subsurface transport from nearby agricultural applications. Indeed, detections of cyanazine, atrazine, metolachlor, and alachlor in rainfall and stormwater runoff in a small urban watershed in Minneapolis, MN, where none of the compounds had been applied (Capel et al., 1998), as well as the results from other studies (e.g., Nations and Hallberg, 1992; Rawn et al., 1998; Hoffman et al., 2000), demonstrate that these and other pesticides may be carried by atmospheric transport from nearby application areas into watersheds where they are not used. For simazine, the similarity between the agricultural and urban areas with respect to detection frequencies in shallow ground water (Fig. 2) is consistent with the fact that the nationwide use of this herbicide was nearly as high in nonagricultural settings as in agricultural locations at the time of sampling (Fig. 3).

Comparisons of the results from the NAWQA investigation with those from other multistate studies reinforce the relations between herbicide detections and land-use setting described above. Figure 4 displays such comparisons for atrazine and metolachlor. Similar plots were provided by Barbash et al. (1999) for cyanazine, prometon, simazine, and alachlor, but not included here because of space considerations. Atrazine and metolachlor were selected for display both because they were the most intensively used triazine and acetanilide herbicides, respectively, at the time of sampling (Fig. 3), and because the results for these compounds from the different multistate studies illustrate some of the potential effects of study design on pesticide detection frequencies (discussed in a later section).

Since, as noted earlier, valid comparisons of detection frequencies among different compounds or studies may be carried out only after correcting for variations in reporting limits, frequencies of herbicide detection in ground water are presented in Fig. 4 relative to the reporting limits for each study. Results from six multistate studies are shown: the NAWQA study, the USGS Midwest Pesticide Study (MWPS; Kolpin et al., 1996b), the NPS (USEPA, 1990, 1992a), the National Alachlor Well-Water Survey (NAWWS; Holden et al., 1992), the Ciba-Geigy Atrazine Study (CGAS; Balu et al., 1998), and the Metolachlor Monitoring Study (MMS; Roux et al., 1991). Owing to the availability of all the results from the NAWQA and MWPS investigations, the data from these two studies are presented as continuous frequency distributions relative to different hypothetical reporting limits, rather than as point values. The NAWQA data are displayed for three study components in the figure; shallow ground water in agricultural and urban 
areas (agricultural and urban LUSs, respectively) and drinking water aquifers (all SUSs). Although the MWPS has involved several rounds of sampling between 1991 and 1994, the data from the 1992 sampling (Kolpin et al., 1995) are shown in Fig. 4 because the 1992 MWPS sampling design was the one most closely resembling that of the NAWQA study (Barbash et al., 1999).

As noted earlier for the NAWQA data alone (Fig. 2), the relative frequencies of detection among the three NAWQA study components and the MWPS, NAWWS, and NPS investigations, shown in Fig. 4, are consistent with patterns of atrazine and metolachlor use. In accord with the fact that their nationwide agricultural use exceeded their nonagricultural use by at least an order of magnitude at the time of sampling (Fig. 3), frequencies of detection of both herbicides were highest for the studies that focused primarily on agricultural areas, i.e., the NAWQA agricultural LUSs and the MWPS.

\section{Statistical Relations between Occurrence and Use in Urban and Agricultural Areas}

In the urban LUSs, the frequencies of detection of the four PMP herbicides and cyanazine at or above 0.01 $\mu \mathrm{g} \mathrm{L}^{-1}$ among all of the 318 sites sampled were positively correlated with their respective intensities of nonagricultural use across the nation (Barbash et al., 1999). This relation was found to be statistically significant among the five compounds $\left(R^{2}=0.85 ; P=0.026\right.$; simple linear correlation between untransformed variables).

Among the 39 agricultural LUSs, the relations observed between frequencies of detection at or above $0.01 \mu \mathrm{g} \mathrm{L}^{-1}$ in ground water and the intensity of agricultural use for the five herbicides (Fig. 5) were qualitatively similar to those reported by, or determined from the results of previous investigations (Barbash and Resek, 1996). Frequencies of detection were generally lower in areas of low use for all of the herbicides, while the highest detection frequencies were usually encountered in areas of more intensive use. Areas with higher use, however, also tended to show greater variability in detection frequencies than areas with lower use. Thus, in general, high use was a necessary, but not a sufficient condition for the frequent detection of an herbicide in shallow ground water beneath agricultural areas.

Statistically significant linear correlations between detection frequencies and use among the agricultural LUSs were observed for atrazine and metolachlor $(P<$ 0.003 ), but not for simazine, alachlor, or cyanazine (Fig. $5)$. When these relations were examined from a nonparametric perspective, however, they were found to be statistically significant for atrazine, metolachlor, alachlor, and cyanazine $(P<0.02$; Spearman rank correlations), but not simazine, suggesting that the relations for alachlor and cyanazine may have been nonlinear. The absence of a significant correlation between detection frequency and use for simazine (Fig. 5) was caused, in part, by its relatively high frequencies of detection in some of the study areas with lower agricultural use-a potential consequence of its extensive use in nonagricultural settings (Fig. 3). Substantial nonagricultural use may also explain why atrazine was detected relatively frequently in some areas with low agricultural use (Fig. 5).

The considerable scatter in the data shown in Fig. 5 (and the correspondingly low $R^{2}$ and Spearman's $\rho$ values) indicates that, as might be expected, herbicide detection frequencies in shallow ground water are controlled by other factors in addition to use. Multiple regression analysis was therefore employed to explore the influence of some of these other explanatory variables.

\section{Influence of Herbicide Properties and Well Depth on Herbicide Detections}

All other natural and anthropogenic factors being equal, the likelihood of detecting a pesticide in ground water, compared with another, is directly related to its mobility in the aqueous phase and its persistence in soil. Although the results from a number of field and laboratory studies support this hypothesis, patterns of pesticide detection derived from large-scale ground water monitoring investigations often do not. By contrast, well depth, one of the parameters examined most frequently in relation to pesticide detections, has commonly been found to vary inversely with the frequency of detection (Barbash and Resek, 1996). The data from the NAWQA program provide an opportunity to determine the extent to which frequencies of herbicide detection in ground water are correlated with these variables.

Initial analysis of the NAWQA LUS results by Kolpin et al. (1998a) using Spearman rank correlations indicated that among the 20 pesticides detected at or above $0.01 \mu \mathrm{g} \mathrm{L}^{-1}$ in shallow ground water beneath agricultural areas, the frequencies of detection were significantly related to the agricultural use and subsurface mobility $\left(K_{\mathrm{oc}}\right)$ of the compounds $(P<0.05$, Spearman rank correlation), but not to their field dissipation half-lives. Through an examination of mutivariate correlations, this paper extends the analysis of Kolpin et al. (1998a) for the four PMP herbicides and cyanazine to examine the degree to which their detection frequencies in shallow ground water beneath agricultural areas were related to their agricultural use, $K_{\mathrm{oc}}$ and aerobic soil halflives (Table 2), as well as the median well depths of the sampled networks (Barbash et al., 1999). As with the previous multivariate analysis of the NAWQA LUS data presented by Kolpin et al. (1998a), and for the reasons discussed earlier, these computations were carried out following the log transformation of all variables.

The multiple regression results indicate that the frequencies with which the PMP herbicides and cyanazine were detected in shallow ground water during the agricultural LUSs were significantly correlated with their aerobic soil half-lives and their agricultural use in the individual LUSs $(P \leq 0.0001$ for each parameter $)$, but not with their $K_{\mathrm{oc}}(P=0.19)$ or the median well depth of the sampled networks $(P=0.72)$. Overall, however, variations in agricultural use and aerobic soil half-life accounted for $<40 \%$ of the observed variability in detection frequencies (adjusted $R^{2}=0.36$ for the regression with all four parameters, as well as for the regression with use and half-life alone). 

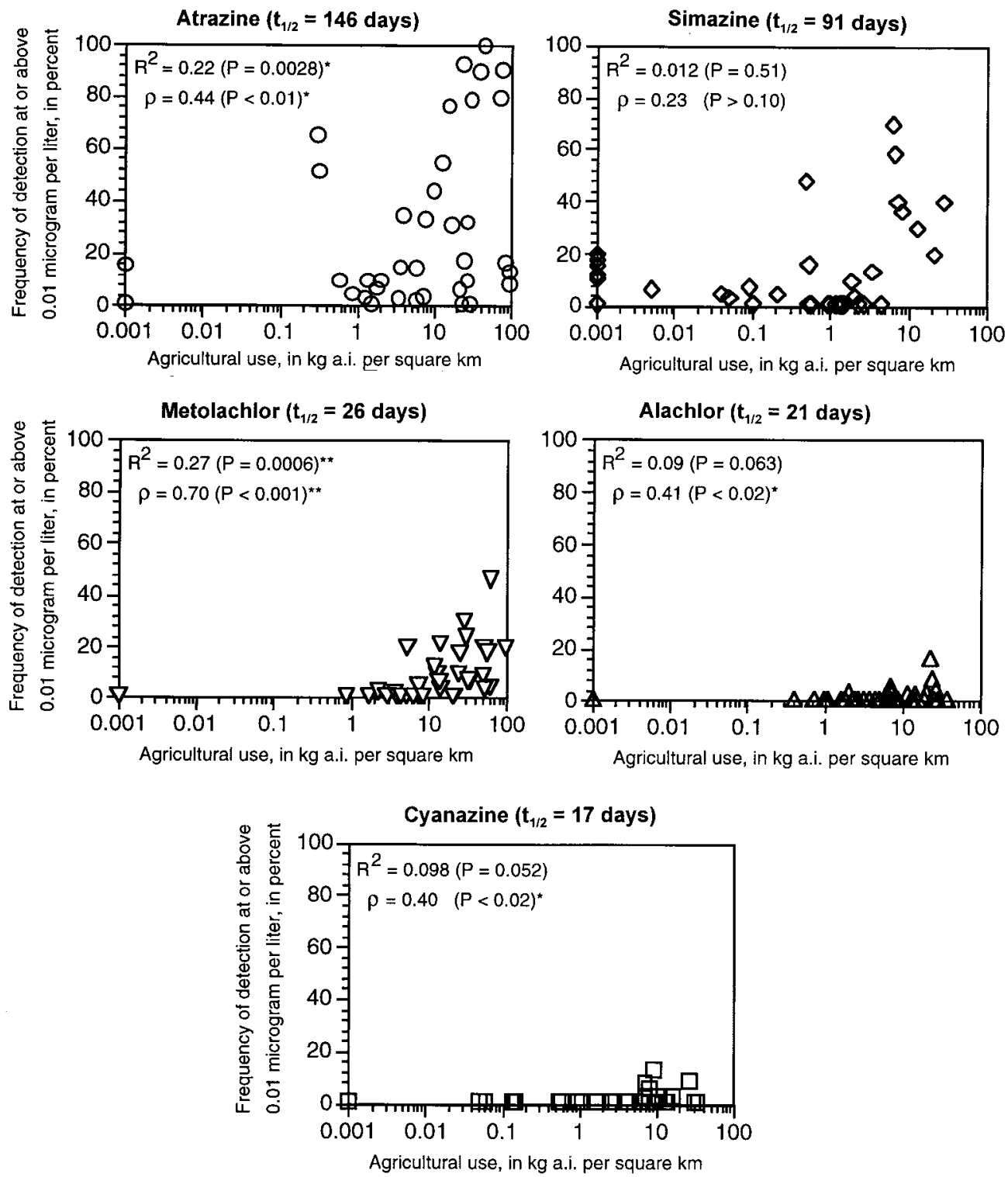

Fig. 5. Frequencies of herbicide detection in shallow ground water for NAWQA land-use studies conducted in agricultural areas, in relation to total agricultural use within a 1-km radius of all sites sampled for each study. Studies with zero use assigned a value of $0.001 \mathrm{~kg}$ a.i. per square kilometer to accomodate log scale (see text). a.i., active ingredient; $\boldsymbol{R}^{2}$, coefficient of determination for linear correlation; $\rho$, Spearman's rank correlation coefficient; $t_{1 / 2}$, half-life for herbicide transformation in aerobic soil. *, ** Statistically significant at the 0.05 and 0.001 probability levels, respectively.

Both Fig. 4 and Fig. 5 illustrate the significant relation between herbicide detection frequencies and persistence identified by the multiple regression model. In both figures, maximum frequencies of herbicide detection at a given reporting limit (Fig. 4) or intensity of use (Fig. 5) are generally lower for compounds with shorter aerobic soil half-lives. (The herbicides are arranged in order of decreasing persistence in both figures.) This trend is corroborated by the results from a study involving the sampling of 88 municipal wells in Iowa, during which the frequencies of detection of transformation products, relative to those of their respective parent compounds (acetochlor, alachlor, metolachlor, atrazine, and cyanazine), were found to increase with decreasing persistence of the parent compound (Kolpin et al., 1998b).
The nonsignificant correlations of herbicide detection frequencies with $K_{\mathrm{oc}}$ and median well depth were likely caused in part by the relatively narrow range spanned by both explanatory variables. The lack of significant correlation between detection frequencies and $K_{\text {oc }}$ during the multivariate correlation analysis is in marked contrast to the significant, inverse relation observed by Kolpin et al. (1998a) between the two parameters for the NAWQA LUS data. However, this contrast is not necessarily surprising. Only five herbicides were examined for the present case, with $K_{\mathrm{oc}}$ values varying by only a factor of three (Table 2), while Kolpin et al. (1998a) examined all 20 pesticides detected at or above $0.01 \mu \mathrm{g} \mathrm{L}^{-1}$ in the agricultural LUSs-a set of compounds for which $K_{\text {oc }}$ values spanned more than two orders of magnitude. Similarly, as with the nonsignifi- 
cant relation seen here between herbicide detection frequencies and the median depths of the wells in the sampled networks, a lack of a significant correlation between herbicide detection frequencies in near-surface aquifers and well depths during the first year of the MWPS was attributed by Burkart and Kolpin (1993) to the relatively narrow range of well depths examined during their study.

\section{Influence of Time Elapsed Since Application (Acetochlor Results)}

As noted earlier, acetochlor was first registered for use in the USA in 1994. Chemical analyses for the herbicide during the NAWQA LUSs and SUSs began in June of that year (Martin et al., 1999). By the end of 1995, analyses for acetochlor had been carried out at 953 of the 2227 NAWQA LUS and SUS sites of interest (Fig. $2)$. The herbicide was detected in two of the sampled wells, both of which were located in areas of known use (Barbash et al., 1999). In other USGS studies, based on a reporting limit of $0.05 \mu \mathrm{g} \mathrm{L}^{-1}$, acetochlor was not detected in the 38 shallow wells sampled by the MWPS in the summer of 1994 (Kolpin et al., 1996b), but was detected in shallow ground water during the statewide sampling in Iowa in the summers of 1995 (Kolpin et al., 1997) and 1996 (Kolpin et al., 1998b). These observations provide large-scale support for the results from several field-scale studies (discussed by Barbash and Resek, 1996) indicating that some pesticides may reach shallow ground water in detectable concentrations within the first year following their initial application.

\section{Influence of Study Design}

The data shown in Fig. 4 display remarkable agreement among the results from different multistate investigations conducted with similar designs, once variations in reporting limits among studies are accounted for. Conversely, some of the results shown in Fig. 4 suggest that, as has been previously noted (Barbash and Resek, 1996), studies targeting areas of higher risk for pesticide contamination are likely to detect the compounds of interest more frequently than studies employing a more randomized sampling design. Both the CGAS and the MMS explicitly focused their sampling on areas deemed vulnerable to ground water contamination from surface sources, while the NAWQA, MWPS, and NPS investigations selected their sampling sites at random after stratifying according to variables such as land use, well type, and hydrogeologic setting. This pronounced contrast in the criteria used to select sampling sites is likely to be the reason why, even after accounting for variations in reporting limits, the frequencies of atrazine and metolachlor detection by the CGAS and MMS, respectively, were so much higher than those observed by the NAWQA, MWPS, or NPS investigations (Barbash et al., 1999).

The NAWWS also employed a stratified random design (Holden et al., 1992), but one for which wells were more likely to be sampled in areas where ground water was deemed to be more vulnerable to contamination, based on the DRASTIC system for vulnerability assess- ment (Aller et al., 1987). However, the frequencies of herbicide detection during the NAWWS were similar to those during the NAWQA SUSs (Fig. 4; Barbash et al., 1999), an observation that is consistent with the limited success with which the DRASTIC system has been shown to predict actual ground water contamination in the past (Barbash and Resek, 1996).

\section{Geographic Relations between Occurrence and Use}

The statistical analyses of the NAWQA data for five of the herbicides of interest, discussed earlier, indicated the extent to which frequencies of detection in shallow ground water were related to their use in agricultural (Fig. 5) and nonagricultural settings. As a complement to this approach, Fig. 6 displays relations between use and occurrence from a geographical, rather than a statistical perspective. As with Fig. 4, the data for only two of the seven herbicides, atrazine and metolachlor, were selected for display because of space limitations. Barbash et al. (1999) presented maps of this type for six of the herbicides of interest, i.e., all but acetochlor.

Countywide use data are shown in Fig. 6 in relation to the median intensity of agricultural use among all counties in the USA with reported use of the compound of interest, i.e., (i) no estimated countywide use (white); (ii) countywide use greater than zero, but less than the median value among all counties with reported use ( $\tan$ ); and (iii) countywide use greater than or equal to the median value (light brown). As noted elsewhere (Barbash and Resek, 1996; Larson et al., 1997; Barbash et al., 1999), some distortion can occur when pesticide use data are displayed on a countywide basis. In areas where pesticide applications take place in only a relatively small portion of a given county, for example, the areal extent of application will be exaggerated on the map, especially in areas such as the western USA where counties tend to be larger than in other regions of the country.

Each sampling network in Fig. 6 is classified, by symbol shape, according to the four NAWQA study components of interest-shallow ground water in agricultural areas (agricultural LUSs), urban areas (urban LUSs), and areas of mixed land use (shallow SUSs); and deeper aquifers (deeper SUSs). Detection frequencies in the individual NAWQA sampling networks are displayed relative to the median value among all of the networks with one or more detections of the compound of interest, i.e., (i) not detected (blue); (ii) detection frequency greater than zero but less than the median value among all networks with detections (yellow); and (iii) detection frequency greater than or equal to the median value among all networks with detections (red). To provide the most complete picture of geographic variations in occurrence, the frequencies of detection shown in Fig. 6 incorporate all detections for each herbicide, and thus were not adjusted to a common reporting limit for the two compounds. Consequently, these maps cannot be employed to compare detection frequencies between atrazine and metolachlor in specific areas; as noted ear- 
A

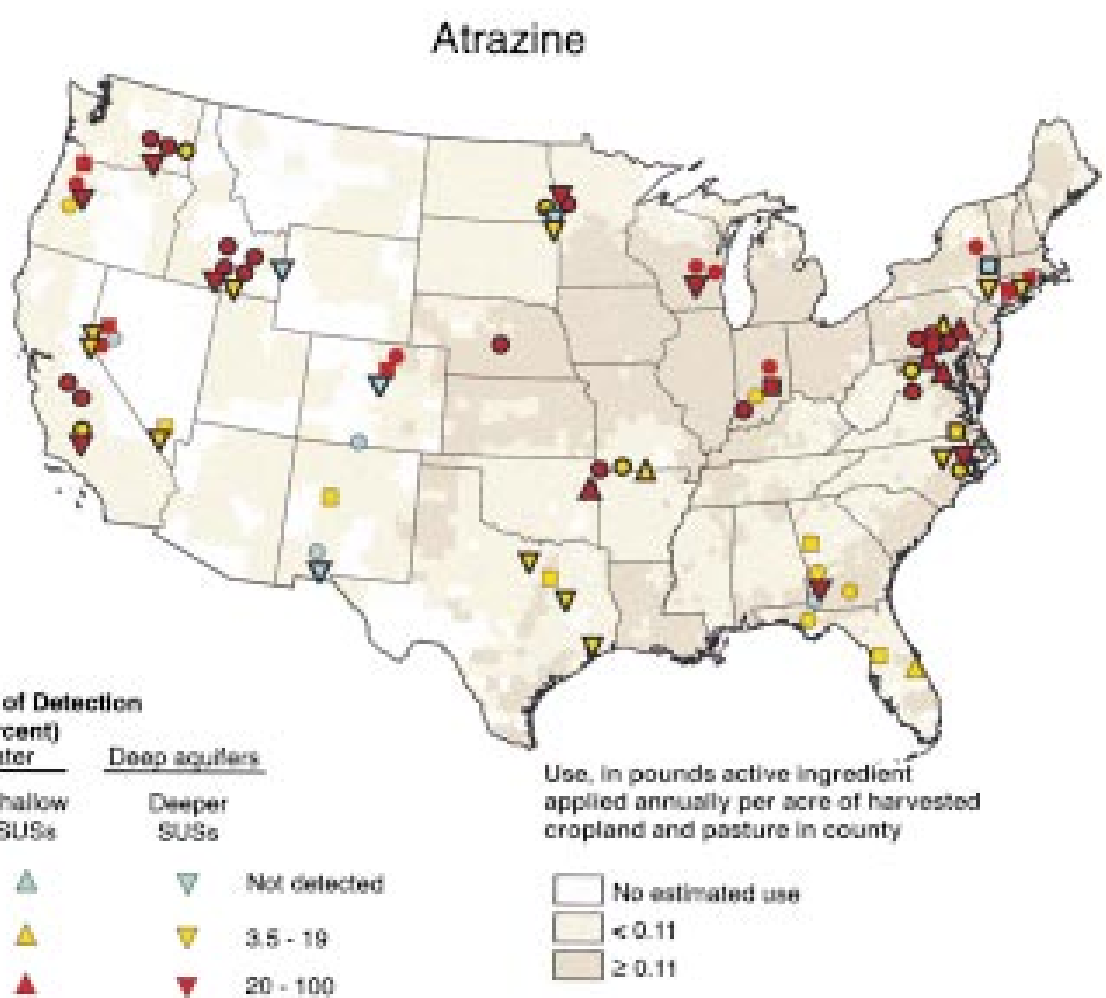

$\boldsymbol{B}$

Metolachlor

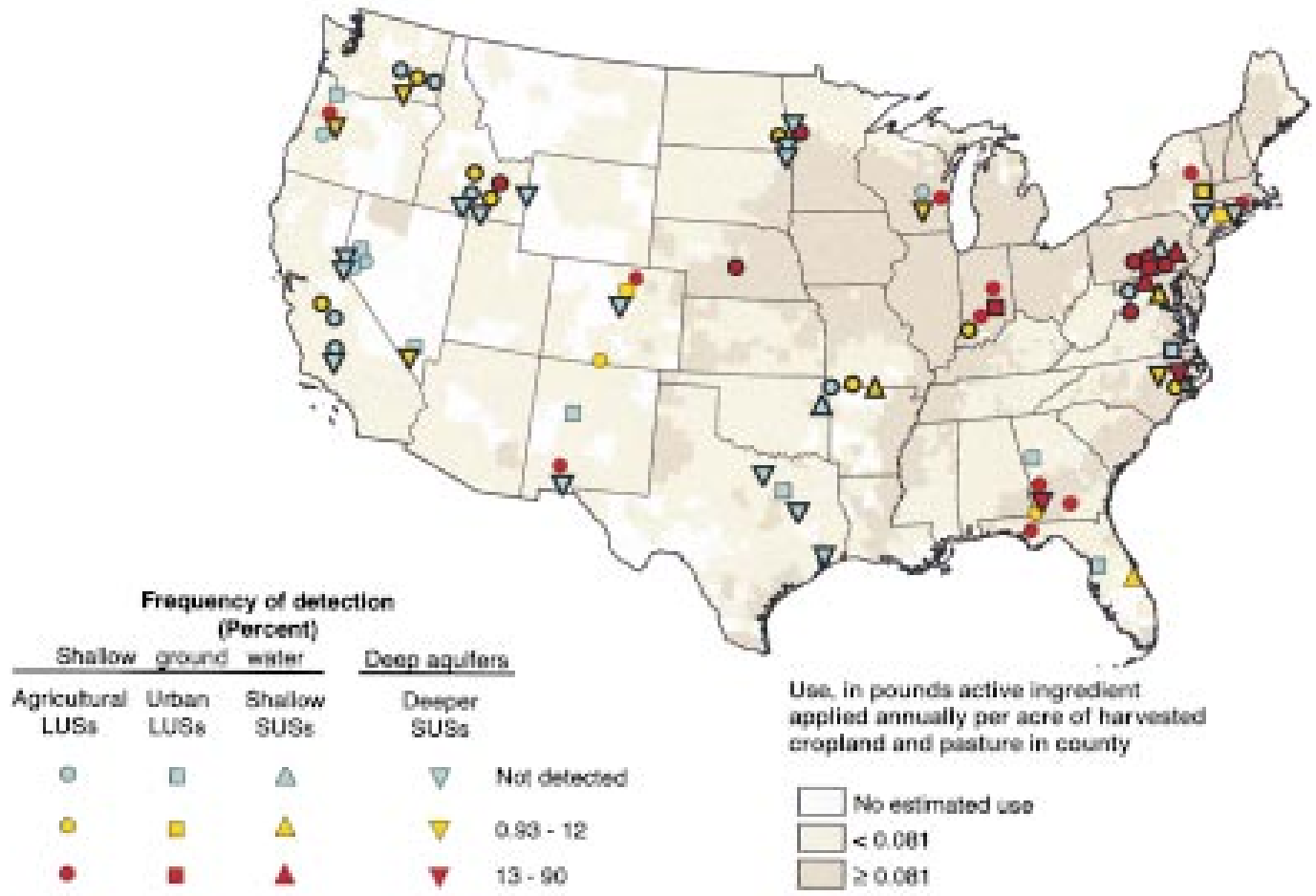

Bold ourined symbols represent drinking-water squitors.

Each symbel represents a network that sampled 10 or mere siles and 75 general location within the NAWOA study area.

Fig. 6. Frequencies of herbicide detection in ground water for the NAWQA study in relation to agricultural use (Gianessi and Anderson, 1996); (a) atrazine, (b) metolachlor. LUSs, land-use studies; SUSs, subunit surveys. 
lier, such comparisons require that the detection frequencies be adjusted to the same reporting limit.

Consistent with the results from the statistical analyses (Fig. 5), Fig. 6 indicates that the geographic correspondence between detections and agricultural use was considerably stronger for metolachlor than for atrazine. High frequencies of atrazine detection (i.e., at or above the median value) were encountered in most of the regions sampled, except for the southern midcontinent and southeast, regardless of land-use setting (Fig. 6a). Thus, relatively little correspondence was observed between the intensity of agricultural use of atrazine and the frequencies of its detection, even in the agricultural areas. Again, these observations are likely to be related to the widespread application of atrazine in nonagricultural, as well as agricultural settings (Fig. 3).

In marked contrast with the atrazine results, Fig. $6 \mathrm{~b}$ indicates that with a few exceptions (mostly in the west), the majority of the sampled networks with high frequencies of metolachlor detection were in areas of high agricultural use. Furthermore, all of the exceptions to this pattern were in agricultural LUSs, where metolachlor was most likely to have been used, though at intensities lower than the national median. High frequencies of metolachlor detection were also encountered in several areas of urban and mixed land use. As discussed earlier, this may have been the result of input from nearby agricultural areas, particularly given that (i) it was only observed in urban areas within regions of high agricultural use and (ii) most of the areas where metolachlor was not detected at all-regardless of land-use settingwere in areas of low agricultural use.

\section{SUMMARY AND CONCLUSIONS}

This paper provides an overview of data on detections in ground water for six high-use, predominantly agricultural herbicides (atrazine, cyanazine, simazine, alachlor, metolachlor, and acetochlor) and a widely used nonagricultural herbicide (prometon), based primarily on sampling conducted by the U.S. Geological Survey from 1993 to 1995 during the National Water-Quality Assessment (NAWQA). Consistent with the results from previous multistate studies of pesticide occurrence in ground water, $98 \%$ of the detections of these herbicides were at concentrations $<1 \mu \mathrm{g} \mathrm{L}^{-1}$. However, criteria for the protection of drinking water quality were exceeded at two sites. Acetochlor, first used in the USA in 1994, was detected at two of the 991 sites sampled for the herbicide through 1995 by the NAWQA program and another USGS investigation, the Midwest Pesticide Study. The timing of these and other, subsequent acetochlor detections supports the observation from previous field-scale studies that some pesticides may be detected in shallow ground water within a year following their application.

High frequencies of herbicide detection in shallow ground water were more likely to be encountered in areas of more intensive herbicide use, but the strength of this relation varied considerably among different compounds, land-use settings, and geographic regions. Frequencies of detection of atrazine, cyanazine, sima- zine, alachlor, and metolachlor at or above $0.01 \mu \mathrm{g} \mathrm{L}^{-1}$ at 318 sites in urban locations across the nation were positively correlated with their respective rates of nonagricultural use nationwide $(P<0.05$; simple linear correlation). In agricultural settings, frequencies of detection in 39 different study areas were positively correlated with agricultural use within a 1-km radius surrounding the sampled sites (Spearman rank correlations) for atrazine, cyanazine, alachlor, and metolachlor, but not for simazine, perhaps because of its extensive nonagricultural use. In shallow ground water beneath agricultural areas and in drinking water aquifers, atrazine was the herbicide detected most frequently, consistent with it having been the pesticide applied most extensively in the nation before sampling. In the urban areas, however, prometon-used almost exclusively in nonagricultural settings-was the herbicide detected most often, in agreement with the results from previous studies.

Multiple regression analysis indicated that the frequencies of atrazine, cyanazine, simazine, alachlor, and metolachlor detection in shallow ground water in agricultural settings were significantly correlated with the agricultural use of these compounds in each of the sampled areas and with their half-lives for transformation in aerobic soil, but not with their soil organic $\mathrm{C}$ partition coefficients $\left(K_{\mathrm{oc}}\right)$ or the median well depths of the sampled networks. The absence of significant relations with well depth or $K_{\text {oc }}$ was attributed to the relatively narrow range examined for both parameters. Variations in aerobic soil half-lives and agricultural use accounted for $<40 \%$ of the overall variability in the frequencies of detection of these five herbicides in shallow ground water beneath agricultural areas (adjusted $R^{2}=0.36$ ). This demonstrates the need to incorporate other parameters into this analysis. Future examination of the NAWQA data will therefore consider additional natural and anthropogenic factors that may be associated with pesticide detections in ground water, including those relating to soil properties, hydrogeologic setting, climate, and agricultural management practices.

Analysis of the results from the NAWQA study to date underscores the need for more detailed information on pesticide use. Limitations on current information regarding the spatial distributions of pesticide use in the USA - particularly for pesticides applied in nonagricultural settings - may have contributed to the relatively poor correspondence observed between herbicide detections and use across the nation for this investigation. The incorporation of more explanatory factors, as well as refinements in the data on pesticide use, will help advance current understanding of how environmental setting and land-use practices influence the likelihood of detecting pesticides in ground water after they are applied to the land.

\section{ACKNOWLEDGMENTS}

The authors would like to thank the U.S. Environmental Protection Agency's Office of Pesticide Programs (OPP) for providing financial support for the preparation of this paper, as well as all of the members of the NAWQA study units who 
were responsible for selecting the sampling sites, installing the wells, collecting the water samples, providing their pesticide occurrence data, and offering local expertise on their respective study areas. The authors would also like to thank Tom Nolan, George Groschen (USGS), Richard Lowrance (USDAARS), and three anonymous reviewers for providing very constructive and valuable comments, and Arty Williams, Charles Evans and John Simons (OPP) for their additional input.

\section{REFERENCES}

Aller, L., T. Bennett, J.H. Lehr, R. Petty, and G. Hackett. 1987. DRASTIC: A standardized system for evaluating ground water pollution potential using hydrogeologic settings. USEPA Rep. 600/ 2-87/035. USEPA, R.S. Kerr Environ. Research Lab., Ada, OK.

Anderson, J.R., E.E. Hardy, J.T. Roach, and R.E. Witmer. 1976. A land use and land cover classification system for use with remote sensor data. U.S. Geol. Surv. Prof. Pap. 964.

Ator, S.W., and M.J. Ferrari. 1997. Nitrate and selected pesticides in ground water of the Mid-Atlantic Region. U.S. Geol. Surv. Water Resour. Invest. Rep. 97-4139.

Bailey, G.W., and J.L. White. 1964. Review of adsorption and desorption of organic pesticides by soil colloids, with implications concerning pesticide bioactivity. J. Agric. Food Chem. 12:324-331.

Balu, K., P.W. Holden, L.C. Johnson, and M.W. Cheung. 1998. Summary of Ciba Crop Protection groundwater monitoring study for atrazine and its degradation products in the United States. In L.G. Ballantine et al. (ed.) Triazine herbicides: Risk assessment. ACS Symp. Ser. 683:227-238.

Barbash, J.E. 1995. Pesticides in ground water: Current understanding of distribution and major influences. U.S. Geol. Surv. Fact Sheet FS-244-95. Available online at http://ca.water.usgs.gov/pnsp/gw/ (verified 18 Jan. 2001).

Barbash, J.E., and E.A. Resek. 1996. Pesticides in ground water: Distribution, trends, and governing factors. Pesticides in the Hydrologic System Series, Vol. 2. CRC Press, Boca Raton, FL.

Barbash, J.E., G.P. Thelin, D.W. Kolpin, and R.J. Gilliom. 1999. Occurrence of major herbicides in ground water of the United States: Results from sampling by the U.S. Geol. Surv. Water Resour. Invest. Rep. 98-4245. Available online at http://water.wr.usgs. gov/pnsp/rep/wrir984245/ (verified 18 Jan. 2001).

Browner, C.M. 1996. Pesticides and ground water state management plan regulation: Proposed rule. Fed. Regist. (26 June 1996). 61: 33260-33301.

Burkart, M.J., and D.W. Kolpin. 1993. Hydrologic and land-use factors associated with herbicides and nitrate in near-surface aquifers. J. Environ. Qual. 22:646-656.

Capel, P.D., M. Lin, and P.J. Wotzka. 1998. Wet atmospheric deposition of pesticides in Minnesota, 1989-1994. U.S. Geol. Surv. Water Resour. Invest. Rep. 97-4026.

Capel, P.D., A.H. Spexet, and S.J. Larson. 1999. Occurrence and behavior of the herbicide prometon in the hydrologic system. Environ. Sci. Technol. 33:674-680.

Christenson, S.C, and A. Rea. 1993. Ground-water quality in the Oklahoma City urban area. p. 589-611. In W.M. Alley (ed.) Regional ground-water quality. Van Nostrand Reinhold, New York, NY.

Cowdery, T.K. 1997. Shallow ground-water quality beneath cropland in the Red River of the North Basin, Minnesota and North Dakota, 1993-1995. U.S. Geol. Surv. Water Resour. Invest. Rep. 97-4001.

Domagalski, J.L., N.M. Dubrovsky, and C.R. Kratzer. 1997. Pesticides in the San Joaquin River, California: Inputs from dormant sprayed orchards. J. Environ. Qual. 26:454-465.

Exner, M.E., and R.F. Spalding. 1990. Occurrence of pesticides and nitrate in Nebraska's ground water. Univ. of Nebraska Water Center, Inst. of Agric. and Natural Resources, Lincoln, NE.

Gianessi, L.P., and J.E. Anderson. 1996. Pesticide use in U.S. crop production: National data report (February 1995, revised April 1996). National Center for Food and Agric. Policy, Washington, DC.

Gianessi, L.P., and C. Puffer. 1990. Herbicide use in the United States. Resources for the Future, Washington, DC.

Gilliom, R.J., W.M. Alley, and M.E. Gurtz. 1995. Design of the National Water-Quality Assessment Program: Occurrence and distri- bution of water-quality conditions. U.S. Geol. Surv. Circ. 1112 Available online at http://water.usgs.gov/pubs/circ1112/ (verified 18 Jan. 2001).

Gilliom, R.J., J.E. Barbash, D.W. Kolpin, and S.J. Larson. 1999. Testing water quality for pesticide pollution. Environ. Sci. Technol. 33:164A-169A. Available online at http://pubs.acs.org/hotartcl/est/ 99/apr/test.html (verified 31 Jan. 2001).

Gilliom, R.J., D.K. Mueller, and L.H. Nowell. 1998. Methods for comparing water-quality conditions among National Water-Quality Assessment study units, 1992-1995. U.S. Geol. Surv. Open-File Rep. 97-589. Available online at http://water.wr.usgs.gov/pnsp/rep/ ofr97589/ (verified 18 Jan. 2001).

Gilliom, R.J., and G.P. Thelin. 1997. Classification and mapping of agricultural land for National Water-Quality Assessment. U.S. Geol. Surv. Circ. 1131. Available online at http:// ca.water.usgs.gov/ pnsp/circ1131/ (verified 31 Jan. 2001).

Goetsch, W.D., D.P. McKenna, and T.J. Bicki. 1992. Statewide survey for agricultural chemicals in rural, private water-supply wells in Illinois. Illinois Dep. of Agric., Bureau of Environ. Programs, Springfield, IL.

Helsel, D.R., and R.M. Hirsch. 1992. Statistical methods in water resources. Studies in Environ. Sci. 49. Elsevier, New York, NY.

Hoffman, R.S., P.D. Capel, and S.J. Larson. 2000. Comparison of pesticides in eight U.S. urban streams. Environ. Toxicol. Chem. 19:2249-2258

Holden, L.R., J.A. Graham, R.W. Whitmore, W.J. Alexander, R.W. Pratt, S.K. Liddle, and L.L. Piper. 1992. Results of the National Alachlor Well Water Survey. Environ. Sci. Technol. 26:935-943.

Jones, J. 2000. Cyanazine; cancellation order. Fed. Regist. (6 Jan. 2000). 65:771-773.

Kenaga, E.E. 1980. Predicted bioconcentration factors and soil sorption coefficients of pesticides and other chemicals. Ecotoxicol. Environ. Saf. 4:26-38.

Klaseus, T.G., G.C. Buzicky, and E.C. Schneider. 1988. Pesticides and groundwater: Surveys of selected Minnesota wells. Minn. Dep. of Health, Minneapolis, MN, and Minn. Dep. of Agric., St. Paul, MN.

Kolpin, D.W., J.E. Barbash, and R.J. Gilliom. 1998a. Occurrence of pesticides in shallow ground water of the United States: Initial results from the National Water-Quality Assessment Program. Environ. Sci. Technol. 32:558-566. Available online at http://ca.water. usgs.gov/pnsp/ja/est32/ (verified 18 Jan. 2001).

Kolpin, D.W., D.A. Goolsby, and E.M. Thurman. 1995. Pesticides in near-surface aquifers: An assessment using highly sensitive analytical methods and tritium. J. Environ. Qual. 24:1125-1132.

Kolpin, D.W., S.J. Kalkhoff, D.A. Goolsby, D.A. Sneck-Fahrer, and E.M. Thurman. 1997. Occurrence of selected herbicides and herbicide degradation products in Iowa's ground water, 1995. Ground Water 35:679-688.

Kolpin, D.W., B.K. Nations, D.A. Goolsby, and E.M. Thurman. 1996a. Acetochlor in the hydrologic system in the midwestern United States, 1994. Environ. Sci. Technol. 30:1459-1464.

Kolpin, D.W., E.M. Thurman, and D.A. Goolsby. 1996b. Occurrence of selected pesticides and their metabolites in near-surface aquifers of the midwestern United States. Environ. Sci. Technol. 30:335-340.

Kolpin, D.W., E.M. Thurman, and M. Linhart. 1998b. The environmental occurrence of herbicides: The importance of degradates in ground water. Arch. Environ. Contam. Toxicol. 35:385-390.

Koterba, M.T., F.D. Wilde, and W.W. Lapham. 1995. Ground-water data-collection protocols and procedures for the National WaterQuality Assessment Program: Collection and documentation of water-quality samples and related data. U.S. Geol. Surv. OpenFile Rep. 95-399.

Kross, B.C., G.R. Hallberg, D.R. Bruner, R.D. Libra, K.D. Rex, L.M.B. Weih, M.E. Vermace, L.F. Burmeister, N.H. Hall, K.L. Cherryholmes, J.K. Johnson, M.I. Selim, B.K. Nations, L.S. Seigley, D.J. Quade, A.G. Dudler, K.D. Sesker, M.A. Culp, C.F. Lynch, H.F. Nicholson, and J.P. Hughes. 1990. The Iowa state-wide rural well-water survey water quality data: Initial analysis. Tech. Inf. Ser. 19. Iowa Dep. of Natural Resources, Iowa City, IA.

Lapham, W.W., F.D. Wilde, and M.T. Koterba. 1995. Ground-water data-collection protocols and procedures for the National WaterQuality Assessment Program: Selection, installation, and documentation of wells, and collection of related data. U.S. Geol. Surv. Open-File Rep. 95-398. 
Larson, S.J., P.D. Capel, and M.S. Majewski. 1997. Pesticides in surface waters: Distribution, trends, and governing factors. Pesticides in the Hydrologic System Series, Vol. 3. CRC Press, Boca Raton, FL.

Lindley, C.E., J.T. Stewart, and M.W. Sandstrom. 1996. Determination of low concentrations of acetochlor in water by automated solidphase extraction and gas chromatography with mass-selective detection. J. Assoc. Off. Anal. Chem. Int. 79:962-966.

Majewski, M.S., and P.D. Capel. 1995. Pesticides in the atmosphere: Distribution, trends, and governing factors. Pesticides in the Hydrologic System Series, Vol. 1. CRC Press, Boca Raton, FL.

Martin, J.D., R.J. Gilliom, and T.L. Schertz. 1999. Summary and evaluation of pesticides in field blanks collected for the National Water-Quality Assessment Program, 1992-1995. U.S. Geol. Surv. Open-File Rep. 98-412. Available online at http://water.wr.usgs. gov/pnsp/rep/ofr98412.pdf (verified 31 Jan. 2001).

Nash, R.G. 1988. Dissipation from soil. p. 131-169. In R. Grover (ed.) Environmental chemistry of herbicides, Vol. 1. CRC Press, Boca Raton, FL.

Nations, B.K., and G.R. Hallberg. 1992. Pesticides in Iowa precipitation. J. Environ. Qual. 21:486-492.

Nowell, L.H., P.D. Capel, and P.D. Dileanis. 1999. Pesticides in stream sediment and aquatic biota: Distribution, trends and governing factors. Pesticides in the Hydrologic System Series, Vol. 4. CRC Press, Boca Raton, FL.

Rawn, D.R., T.H.J. Halldorson, and D.C.G. Muir. 1998. Atmospheric transport and deposition, an additional input pathway for atrazine to surface waters. In L.G. Ballantine et al. (ed.) Triazine herbicides: Risk assessment. ACS Symp. Ser. 683:158-176.

Roux, P.H., K. Balu, and R. Bennett. 1991. A large-scale retrospective ground water monitoring study for metolachlor. Ground Water Monit. Rev. 11:104-114.

Rudolph, D., J. Goss, A. Graham, G. Kachanoski, M. Scafe, D. Aspinall, R. van den Broek, S. Clegg, D. Barry, and J. Stimson. 1992. Ontario farm groundwater quality survey winter 1991/92. Univ. of Waterloo Centre for Ground Water Res., Waterloo, ON, Canada.

Rudolph, D., J. Goss, A. Graham, G. Kachanoski, M. Scafe, D. Aspinall, R. van den Broek, S. Clegg, D. Barry, and J. Stimson. 1993. Ontario farm groundwater quality survey summer 1992. Univ. of Waterloo Centre for Ground Water Res., Waterloo, ON, Canada.

Schwarzenbach, R.P., P.M. Gschwend, and D.M. Imboden. 1993. Environmental organic chemistry. John Wiley \& Sons, New York, NY.

Sievers, D.M., and C.D. Fulhage. 1992. Survey of rural wells in Missouri for pesticides and nitrate. Ground Water Monit. Rev. 12: $142-150$.

Squillace, P.J., J.S. Zogorski, W.G. Wilber, and C.V. Price. 1996. Preliminary assessment of the occurrence and possible sources of MTBE in groundwater in the United States, 1993-1994. Environ. Sci. Technol. 30:1721-1730.

Steichen, J., J. Koelliker, D. Grosh, A. Heiman, R. Yearout, and V. Robbins. 1988. Contamination of farmstead wells by pesticides, volatile organics, and inorganic chemicals in Kansas. Ground Water Monit. Rev. 8:153-159.

Thelin, G.P., and L.P. Gianessi. 2000. Method for estimating pesticide use for county areas of the conterminous United States. U.S. Geol. Surv. Open-File Rep. 00-250. Available online at http://water.wr. usgs.gov/pnsp/rep/ofr00250/ (verified 19 Jan. 2001).

U.S. Department of Agriculture-Agricultural Research Service. 1995. Pesticide properties database. Available online at http://wizard. arsusda.gov/acsl/ppdb.html (last update May, 1995; accessed 11 Mar. 1998; verified 31 Jan. 2001).

U.S. Department of Commerce. 1995. 1992 Census of AgricultureGeographic Area Series 1B, U.S. Summary and County Level Data, 1992. U.S. Dep. of Commerce, Bureau of the Census, Washington, DC.

U.S. Environmental Protection Agency. 1990. National survey of pesticides in drinking water wells: Phase 1 Rep. USEPA Rep. 570/9-
90-015. USEPA, Office of Pesticides and Toxic Substances, Washington, DC.

U.S. Environmental Protection Agency. 1991. Pesticides and groundwater strategy. USEPA Rep. 21T-1022. USEPA, Office of Pesticides and Toxic Substances, Washington, DC.

U.S. Environmental Protection Agency. 1992a. Another looknational survey of pesticides in drinking water wells: Phase 2 Rep. USEPA Rep. 579/09-91/020. Available from National Tech. Inf. Service, Springfield, VA, as NTIS Rep. PB 91-125765. U.S. Gov. Print. Office, Washington, DC

U.S. Environmental Protection Agency. 1992b. Guidelines establishing test procedures for the analysis of pollutants (App. B, Part 136 Definition and procedures for the determination of the method detection limit). U.S. Code of Fed. Reg., Title 40:565-567.

U.S. Environmental Protection Agency. 1993a. Guidance for pesticides and ground water state management plans. USEPA Rep. 735-B-93-005a. USEPA, Office of Prevention, Pesticides, and Toxic Substances, Washington, DC.

U.S. Environmental Protection Agency. 1993b. Pesticide environmental fate one-line summary-Prometon. USEPA Office of Pesticide Programs, Environ. Fate and Effects Div., Washington, DC.

U.S. Environmental Protection Agency. 1994a. Pesticide environmental fate one-line summary-Acetochlor. USEPA Office of Pesticide Programs, Environ. Fate and Effects Div., Washington, DC.

U.S. Environmental Protection Agency. 1994b. Pesticide environmental fate one-line summary-Alachlor. USEPA Office of Pesticide Programs, Environ. Fate and Effects Div., Washington, DC.

U.S. Environmental Protection Agency. 1994c. Pesticide environmental fate one-line summary-Metolachlor. USEPA Office of Pesticide Programs, Environ. Fate and Effects Div., Washington, DC.

U.S. Environmental Protection Agency. 1995. Pesticide environmental fate one-line summary-Cyanazine. USEPA Office of Pesticide Programs, Environ. Fate and Effects Div., Washington, DC.

U.S. Environmental Protection Agency. 1996a. Pesticide environmental fate one-line summary-Atrazine. USEPA Office of Pesticide Programs, Environ. Fate and Effects Div., Washington, DC.

U.S. Environmental Protection Agency. 1996b. Pesticide environmental fate one-line summary-Simazine. USEPA Office of Pesticide Programs, Environ. Fate and Effects Div., Washington, DC.

U.S. Environmental Protection Agency. 2000. Drinking water standards and health advisories. USEPA Rep. 822-B-00-001. USEPA Office of Water, Washington, DC. Available online at http:// www.epa.gov/ost/drinking/standards/dwstandards.pdf (verified 19 Jan. 2001).

U.S. Geological Survey. 1990. Land use and land cover digital data from 1:250,000- and 1:100,000-scale maps. U.S. Geological Survey data user guide, no. 4. Available online at ftp://www-nmd.usgs.gov/ pubLULC/lulcguide/dug4lulc.txt (verified 31 Jan. 2001).

U.S. Geological Survey. 1999. Pesticides in surface and ground water of the United States: Summary of results of the National WaterQuality Assessment Program (NAWQA) Pesticide National Synthesis Project. Available online at http://water.wr.usgs.gov/pnsp/ allsum (last update 23 Sept. 1998; accessed 5 Feb. 1999; verified 19 Jan. 2001).

Whitmore, R.W., J.E. Kelly, and P.L. Reading. 1992. National home and garden pesticide use survey. Vol.1. Executive summary, results, and recommendations. Research Triangle Inst. Rep. RTI/5100/1701F. Research Triangle Inst., Research Triangle Park, NC.

Zaugg, S.D., M.W. Sandstrom, S.G. Smith, and K.M. Fehlberg. 1995. Methods of analysis by the U.S. Geological Survey National Water Quality Laboratory-determination of pesticides in water by C-18 solid-phase extraction and capillary-column gas chromatography/ mass spectrometry with selected-ion monitoring. U.S. Geol. Surv. Open-File Rep. 95-181. Available online at http://wwwnwql.cr. usgs.gov/Public/pubs/OFR95-181/OFR-95-181.html (verified 19 Jan. 2001). 